\title{
The Effect of Lead Exposure through Drinking Water on Symptoms of Nervous System Disorders in Communities Around Pasir Sembung Landfill Cianjur, Indonesia, 2020
}

\author{
Budi Hartono*, R. Siti Mardiyanti Pratiwi \\ Departement of Environmental Health, Faculty of Public Health, Universitas Indonesia, West Java, Indonesia
}

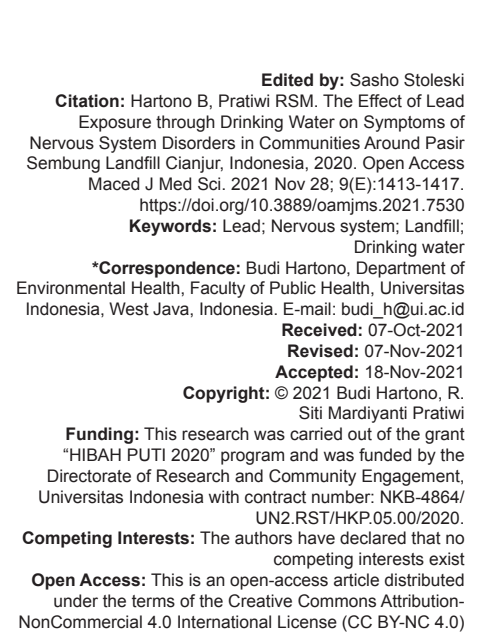

Introduction

The nervous system is the most sensitive system to lead $(\mathrm{Pb})$ toxicity, although the poisoning process occurs over a long period of time with a small absorption rate [1]. $\mathrm{Pb}$ poisoning can occur without obvious symptoms and effects. The effects of $\mathrm{Pb}$ exposure are chronic, so the longer the exposure occurs, the cumulative dose increases progressively [2].

$\mathrm{Pb}$ is a heavy metal which in scientific language is plumbum [3]. Pb has toxic properties that can contaminate food, drink, air, and water. Pb exposure can be through the inhalation, ingestion, skin contact, and parenteral [4].

$\mathrm{Pb}$ absorption through the inhalation is $\pm 40 \%$ and ingestion is $\pm 5-10 \%$. Pb that enters through the mouth will enter the ingestion and will participate in the metabolic process so that it will be stored in the central nervous system, tissues, organs, and blood. $\mathrm{Pb}$ is excreted in the body through the skin, kidneys, and large intestine [5].

$\mathrm{Pb}$ cannot be destroyed, and cannot be broken down into other substances, and accumulates for a long time in the soil so that the $\mathrm{Pb}$ that is present or pollutes the environment can be a threat to the environment and human health around it [6]. In the environment, $\mathrm{Pb}$ can be spread in water, soil, and air from natural processes and from human activities, but $\mathrm{Pb}$ pollution resulting from human activities is a major source of environmental pollution today compared to naturally occurring $\mathrm{Pb}$ [7].

Human activities that can be a source of $\mathrm{Pb}$ pollution it is the waste produces. Wastes are not managed properly will be a source of $\mathrm{Pb}$ pollution, it produces leachate which is causing pollution. Fard et al. [8] stated that leachate generally contains organic and inorganic compounds (heavy metals). The results of studies from MSW Landfill in Poland in 2011, the types of heavy metals found in leachate are timabl, copper, zinc, chromium, and cadmium [9].

Leachate is produced from of complex biochemical and physical processes or the decomposition of waste and/or infiltration of piled up waste so it can endanger the health of people living around the landfill [10]. Leachate discharge and quality's depends on rainfall and the character of the dumped waste. Dangerous leachate usually comes from landfills that use an open dumping process in its waste management. 
Open dumping is an old method of waste management that has been practiced by $3 / 4$ countries in the world [11]. In Indonesia, this method is still popular and used, out of 210 landfills in Indonesia, $86.7 \%$ still use the open dumping method [12]. One of them is the Pasir Sembung landfill which is located in Cilaku District, Cianjur Regency, West Java. Negative impacts from this open dumping are the contamination of groundwater due to the leachate it produces.

Groundwater is a potential water resource as a source of water for consumption to meet daily needs. Provision of ground water as a source of drinking water is always associated with groundwater conditions that are healthy, cheap, and available in an amount that suits your needs. Groundwater resources are renewable in nature because they are an integral part of the hydrological cycle on earth. However, in reality, there are various factors that influence its utilization, both in terms of quantity and quality [13].

Research locations are Kandang Sapi Village, Mekarwangi Village, Baru Village, and Pasir Cabe Village from Cilaku District, Cianjur Regency, West Java, Indonesia where people still use groundwater, namely well water to meet their daily needs such as drinking, cooking, washing, bathing, and others. The four villages are also located in the vicinity of watercourses, which may cause contamination due to leachate generated from the landfill. Therefore, the people living in the vicinity of the Pasir Sembung landfill area are more at risk of health problems, especially due to $\mathrm{Pb}$ contamination of well water from leachate water [14].

\section{Methods}

This research used a cross-sectional study design, conducted in residential areas who live around the Pasir Sembung landfill. The locations were four villages who is close with the Pasir Sembung landfill and on stream with water flow so that contamination of groundwater could occur (Figure 1). The four villages are Kandang Sapi, Mekarwangi, Baru, and Pasir Cabe. This research was conducted from October to December 2020.

The sample size in this study was 86 people from four villages in Cilaku District, Cianjur Regency, West Java, Indonesia with the number of samples from each village as follows:

\begin{tabular}{llll}
\hline Number & Village & Desa & Samples \\
\hline 1 & Kandang Sapi & Sirnagalih & 24 \\
2 & Mekarwangi & Cibinong Hilir & 20 \\
3 & Baru & Cibinong Hilir & 24 \\
4 & Pasir Cabe & Rahong & 18 \\
Total & & & 86 \\
\hline
\end{tabular}

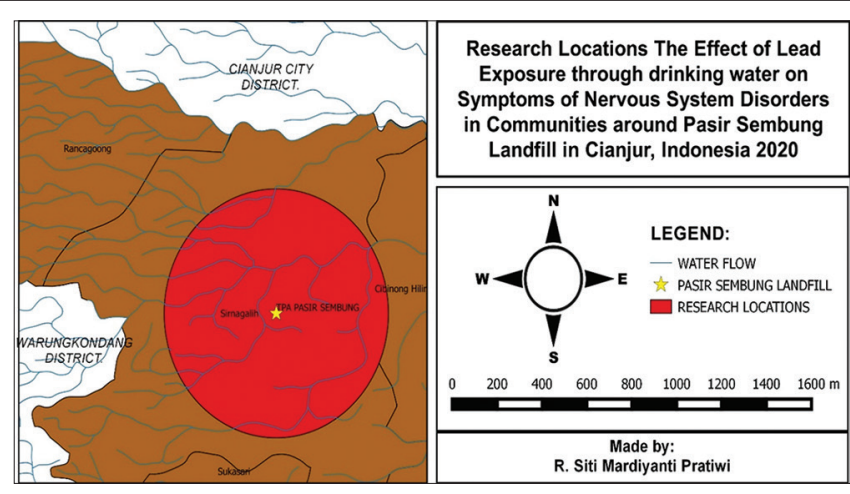

Figure 1: Research Locations. Source: Made by Author with Quantum GIS Apps, 2020

Groundwater samples are groundwater that used as drinking and cooking by respondents. Groundwater samples were taken using 1 liter sample bottle. Total sample taken for analysis was 20 groundwater. Analysis or inspection of well water for $\mathrm{Pb}$ parameters is carried out at an accredited laboratory. Exposure intake for each groundwater sample will be calculated using the following formula:

$$
\mathrm{I}_{\mathrm{nk}}=\frac{\mathrm{C} \times \mathrm{R} \times \mathrm{fE} \times \mathrm{Dt}}{\mathrm{Wb} \times \operatorname{tavg}}
$$

Informations:

$\begin{array}{lll}\mathrm{I}_{\mathrm{nk}} & = & \text { intake }(\mathrm{mg} / \mathrm{kg} / \text { day }) \\ \mathrm{C} & = & \text { risk agent concentration }(\mathrm{mg} / \mathrm{L}) \\ \mathrm{R} & = & \text { consumption rate }(\mathrm{L} / \text { day }) \\ \mathrm{f}_{\mathrm{E}} & = & \text { frequency of exposure (day/year) } \\ \mathrm{D}_{\mathrm{t}} & = & \text { duration of exposure (years) } \\ \mathrm{W}_{\mathrm{b}} & = & \text { respondent's body weight }(\mathrm{kg}) \\ \mathrm{t}_{\text {avg }} & = & \text { average time period }(30 \text { years } \mathrm{x} \\ & & 365 \text { days/year })\end{array}$

\section{Results}

\section{Pb exposure intake}

$\mathrm{Pb}$ exposure intake through drinking water consumed by 86 people around the Pasir Sembung landfill was made into a categorical with the cutoff point is median $(0.0000655250 \mathrm{mg} / \mathrm{kg} /$ day $)$. The categorization shows that people with $\mathrm{Pb}$ exposure intake >median and $\leq$ median is the same, it is 43 people each. $\mathrm{Pb}$ exposure intake and $\mathrm{Pb}$ exposure categories through drinking water in people around Pasir Sembung landfill in 2020 are shown in Tables 1 and 2.

Table 1: Pb exposure intake through drinking water to community around Pasir Sembung Landfill, Cianjur, Indonesia, 2020

\begin{tabular}{lllll}
\hline Variable & $\mathrm{n}$ & Mean & Median & Min - Max \\
\hline $\mathrm{Pb}$ Exposure Intake $(\mathrm{mg} / \mathrm{kg} /$ day) & 86 & 0.0000887462 & 0.0000655250 & $0.00000067-0.00038064$ \\
\hline $\mathrm{Pb}$ Lead. & & & & 0.0000854918 \\
\hline
\end{tabular}


Table 2: Category of $\mathrm{Pb}$ exposure intake through drinking water to community around Pasir Sembung Landfill, Cianjur, Indonesia, 2020

\begin{tabular}{lll}
\hline Pb exposure intake & $\mathrm{n}$ & Percentage $(\%)$ \\
\hline$>0.0000655250 \mathrm{mg} / \mathrm{kg} /$ day & 43 & 50 \\
$\leq 0.0000655250 \mathrm{mg} / \mathrm{kg} /$ day & 43 & 50 \\
Total & 86 & 100 \\
\hline Pb: & &
\end{tabular}

\section{Respondent Characteristics}

Respondents are people who live in the ring around the Pasir Sembung landfill. The characteristics of the respondents studied were only general characteristics and were easy to ask or count. The characteristics of the 86 communities who were respondents in this study are shown in Table 3.

Table 3: Frequency distribution of respondent characteristics around Pasir Sembung Landfill, Cianjur, Indonesia, 2020

\begin{tabular}{lll}
\hline Respondent characteristics & Total & Persentage \\
\hline Age & & \\
$\quad>41$ years & 42 & 48.8 \\
$\quad \leq 41$ years & 44 & 51.2 \\
Sex & & \\
$\quad$ Male & 18 & 20.9 \\
$\quad$ Female & 68 & 79.1 \\
Working & & \\
$\quad$ Not working/housewife & 54 & 62.8 \\
$\quad$ Farmer & 4 & 4.7 \\
$\quad$ Laborer & 8 & 9.3 \\
$\quad$ Self-employed/teacher/working in landfill & 8 & 9.3 \\
$\quad$ Trading & 12 & 14.0 \\
History of diabetes & & \\
$\quad$ Yes & 4 & 4.7 \\
$\quad$ No & 82 & 95.3 \\
History of hypertension & & \\
$\quad$ Yes & 17 & 19.8 \\
$\quad$ No & 69 & 80.2 \\
History of nervous disease & & \\
$\quad$ Yes & 3 & 3.5 \\
$\quad$ No & 83 & 96.5 \\
Smoking & & \\
$\quad$ Yes & 20 & 23.3 \\
$\quad$ No & 66 & 76.7 \\
Home distance from landfill & \\
$\quad \leq 1100 \mathrm{~m}$ & & \\
$\quad>1100 \mathrm{~m}$ & 42 & 48.8 \\
\hline
\end{tabular}

\section{Symptoms of nervous system disorders}

The variable of symptoms of nervous system disorders is divided into two categories, namely, there are symptoms if you have $\geq 1$ symptom and $<1$ or no symptoms if you do not have any symptoms of nervous system disorders.

The results of the interview show that many people experience symptoms of nervous system disorders, with the most symptoms that are complained of is numbness in the hand and headache. Symptoms category and the percentage of nervous system disorder symptoms by 86 communities around the Pasir Sembung landfill is shown in Figures 2 and 3.

\section{Discussion}

\section{Effect of $\mathrm{Pb}$ exposure intake on symptoms} of nervous system disorders

In the study, there was an effect of $\mathrm{Pb}$ exposure intake through drinking water on symptoms of nervous system disorders in the community around Pasir Sembung landfill, Cianjur, Indonesia, 2020. The $p=0.035$ with an $O R=3.150$. The OR indicates that people with $\mathrm{Pb}$ exposure intake through drinking water

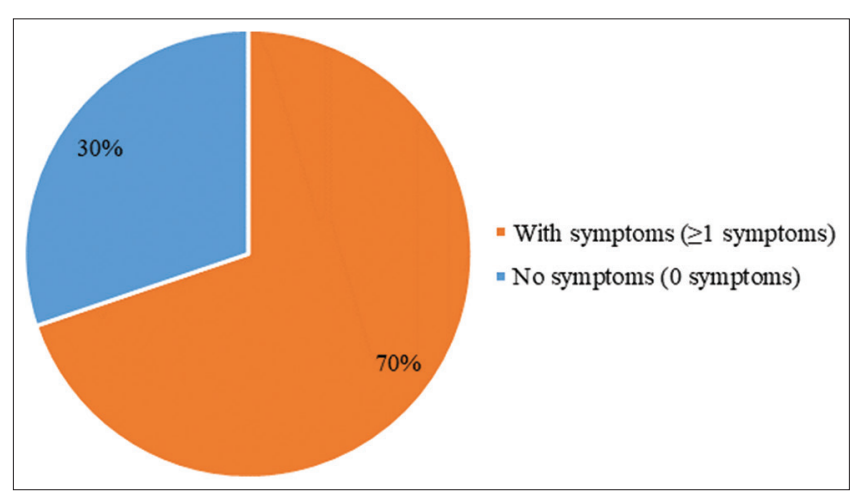

Figure 2: Category of symptoms of nervous system disorders in community around Pasir Sembung Landfill, Cianjur, Indonesia, 2020

$>0.0000655250 \mathrm{mg} / \mathrm{kg} / \mathrm{day}$ have 3.150 times greater risk of experiencing symptoms of nervous system disorders than people with $\mathrm{Pb}$ exposure intake through drinking water $\leq 0.0000655250 \mathrm{mg} / \mathrm{kg} /$ day.

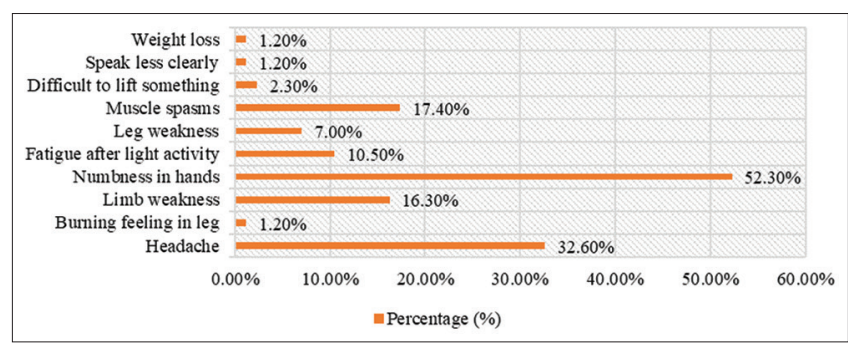

Figure 3: Percentage of symptoms of nervous system disorders in community around Pasir Sembung Landfill, Cianjur, Indonesia, 2020

The results of the analysis of the effect of $\mathrm{Pb}$ exposure intake on symptoms of nervous system disorders in 86 communities around Pasir Sembung landfill, Cianjur, Indonesia, 2020 are shown in Table 4.

Table 4: $\mathrm{Pb}$ exposure intake to symptoms of nervous system disorders in community around Pasir Sembung Landfill, Cianjur, Indonesia, 2020

\begin{tabular}{|c|c|c|c|c|c|c|c|c|}
\hline \multirow[t]{3}{*}{$\mathrm{Pb}$ exposure intake } & \multicolumn{4}{|c|}{$\begin{array}{l}\text { Symptoms of nervous } \\
\text { system disorders }\end{array}$} & \multicolumn{2}{|c|}{ Total } & \multirow[t]{3}{*}{$\mathrm{p}$-value } & \multirow[t]{3}{*}{ OR } \\
\hline & \multicolumn{2}{|c|}{ Yes } & \multicolumn{2}{|l|}{ No } & \multirow[t]{2}{*}{$\mathrm{n}$} & \multirow[t]{2}{*}{$\%$} & & \\
\hline & $\mathrm{n}$ & $\%$ & $\mathrm{n}$ & $\%$ & & & & \\
\hline$>0.0000655250$ & 35 & 81.4 & 8 & 18.6 & 43 & 100 & 0.035 & 3.150 \\
\hline$\leq 0.0000655250$ & 25 & 58.1 & 18 & 41.9 & 43 & 100 & & \\
\hline Total & 60 & 69.8 & 26 & 30.2 & 86 & 100 & & \\
\hline
\end{tabular}

Regulation of the Minister of Health of the Republic of Indonesia No.416/Menkes/SK/IX/90 concerning Clean Water Quality Requirements states that the maximum $\mathrm{Pb}$ concentration is $0.05 \mathrm{mg} / \mathrm{L}$. In contrast to the Indonesian regulations, it is known that the requirements of the $\mathrm{WHO}$ for $\mathrm{Pb}$ concentration in clean water are even more stringent, namely $0.03 \mathrm{mg} / \mathrm{L}$ [15], [16]. Based on these two regulations, from the 20 sample points examined, it is known that all samples still have $\mathrm{Pb}$ concentrations below the required quality standard so that based on the quality of 20 samples still considered feasible.

$\mathrm{Pb}$ exposure intake is influenced by the concentration of $\mathrm{Pb}$ in the water, consumption rate of drinking water, body weight, duration of living, and the frequency of exposure of respondents in the 
Table 5: The effect of other variable on symptoms of nervous system disorders in community around Pasir Sembung Landfill, Cianjur, Indonesia, 2020

\begin{tabular}{|c|c|c|c|c|c|c|c|c|}
\hline \multirow[t]{3}{*}{ Other variable } & \multicolumn{4}{|c|}{ Symptoms of nervous system disorders } & \multicolumn{2}{|c|}{ Total } & \multirow[t]{3}{*}{$\mathrm{p}$-value } & \multirow[t]{3}{*}{ OR } \\
\hline & \multicolumn{2}{|c|}{ Yes } & \multicolumn{2}{|c|}{ No } & \multirow[t]{2}{*}{$\bar{n}$} & \multirow[t]{2}{*}{$\%$} & & \\
\hline & $\mathrm{n}$ & $\%$ & $\mathrm{n}$ & $\%$ & & & & \\
\hline \multicolumn{9}{|l|}{ Age } \\
\hline$>41$ years & 34 & 81.0 & 8 & 19.0 & 42 & 100 & \multirow[t]{2}{*}{0.049} & \multirow[t]{2}{*}{2.942} \\
\hline$\leq 41$ years & 26 & 59.1 & 18 & 40.9 & 44 & 100 & & \\
\hline \multicolumn{9}{|l|}{ Sex } \\
\hline Male & 9 & 50.0 & 9 & 50.0 & 18 & 100 & \multirow[t]{2}{*}{0.078} & \multirow[t]{2}{*}{-} \\
\hline Female & 51 & 75.0 & 17 & 25.0 & 68 & 100 & & \\
\hline \multicolumn{9}{|l|}{ Duration of living } \\
\hline$>30.52$ years & 27 & 71.1 & 11 & 28.9 & 38 & 100 & \multirow[t]{2}{*}{1.000} & \multirow[t]{2}{*}{-} \\
\hline$\leq 30.52$ years & 33 & 68.8 & 15 & 31.2 & 48 & 100 & & \\
\hline \multicolumn{9}{|l|}{ Working } \\
\hline Not working/housewife & 39 & 65.0 & 15 & 57.7 & 54 & 100 & \multirow[t]{5}{*}{0.310} & \multirow[t]{5}{*}{-} \\
\hline Farmer & 4 & 100.0 & 0 & 0.0 & 4 & 100 & & \\
\hline Laborer & 3 & 37.5 & 5 & 62.5 & 8 & 100 & & \\
\hline Self-employed/teacher/working in landfill & 5 & 62.5 & 3 & 37.5 & 8 & 100 & & \\
\hline Trading & 9 & 75.0 & 3 & 25.0 & 12 & 100 & & \\
\hline \multicolumn{9}{|l|}{ History of diabetes } \\
\hline Yes & 4 & 100.0 & 0 & 0.0 & 4 & 100 & \multirow[t]{2}{*}{0.310} & \multirow[t]{2}{*}{-} \\
\hline No & 56 & 68.3 & 26 & 31.7 & 82 & 100 & & \\
\hline \multicolumn{9}{|l|}{ History of hypertension } \\
\hline Yes & 14 & 82.4 & 3 & 17.6 & 17 & 100 & \multirow[t]{2}{*}{0.334} & \multirow[t]{2}{*}{-} \\
\hline No & 46 & 66.7 & 23 & 33.3 & 69 & 100 & & \\
\hline \multicolumn{9}{|l|}{ History of nervous disease } \\
\hline Yes & 3 & 100.0 & 0 & 0.0 & 3 & 100 & 0.550 & - \\
\hline No & 57 & 68.7 & 26 & 31.3 & 83 & 100 & & \\
\hline Smoking & & & & & & & & \\
\hline Yes & 11 & 55.0 & 9 & 45.0 & 20 & 100 & 0.173 & - \\
\hline No & 49 & 74.2 & 17 & 25.8 & 66 & 100 & & \\
\hline Home distance from landfill & & & & & & & & \\
\hline$\leq 1100 \mathrm{~m}$ & 29 & 69.0 & 13 & 31.0 & 42 & 100 & 1.000 & - \\
\hline$>1100 \mathrm{~m}$ & 31 & 70.5 & 13 & 29.5 & 44 & 100 & & \\
\hline
\end{tabular}

environment. The results of the calculation show that the highest exposure intake is $0.0003806382 \mathrm{mg} / \mathrm{kg} / \mathrm{day}$, with a $\mathrm{Pb}$ concentration $0.0029483 \mathrm{mg} / \mathrm{L}$, consumption rate of drinking water is $2.8 \mathrm{~L} / \mathrm{day}$, bodyweight is $40.9 \mathrm{~kg}$, duration of living in that location for 59 years (from birth), and never left that location. Whereas the smallest exposure intake was $0.0000006728 \mathrm{mg} / \mathrm{kg} / \mathrm{day}$ with a $\mathrm{Pb}$ concentration is $0.0000293 \mathrm{~m} / \mathrm{L}$, consumption rate of drinking water $1.6 \mathrm{~L} /$ day, bodyweight $49 \mathrm{~kg}$, duration of living in that location for 22 years (from birth), and also never left the location.

Symptoms of nervous system disorders by 86 communities around Pasir Sembung landfill, Cianjur, Indonesia were obtained from the results of interviews using a questionnaire based on the Adult $\mathrm{Pb}$ Poisoning Medical Provider Questionnaire found in the California Department of Public Health in 2009 [16]. People who were respondents in this study were not subjected to physical examinations to strengthen the symptoms of nervous system disorders they were experiencing, researchers only observed visually. The results of the interviews and observations show that the average person experiences numbness in hand.

\section{Effect of other variable on symptoms of nervous system disorders}

The other analyzes revealed that another variable that had an influence on symptoms of nervous system disorders in 86 communities around Pasir Sembung landfill, Cianjur, Indonesia in 2020 was age, while other variable had no effect. The $p=0.049$ and an OR $=2.942$. The OR indicates that people aged $>41$ years have a risk of 2.942 times greater to experience symptoms of nervous system disorders than people with age $\leq 41$ years. The results of the analysis of the effect of other variable on symptoms of nervous system disorders in 86 communities around the Pasir Sembung landfill, Cianjur, Indonesia, 2020 are shown in Table 5.

In this research, age is one of the factors that influence nervous system disorders experienced by the respondents studied. According to a neuroscientist from the Neurology Department of the Hasanudin University Makassar, Dr. Abdul Muis Sp. S, aging is one of the factors that can affect the occurrence of neuropathy or conditions that affect the nervous system, in which nerve fibers become damaged as a result of injury or disease. This happens a lot in patients who are over 40 years old. Neuropathy generally affects about $26 \%$ or one in four who are 40 years and over [18].

\section{Conclusion}

The results of the study show that the intake of $\mathrm{Pb}$ exposure through drinking water affects the symptoms of nervous system disorders in the communities around Pasir Sembung landfill, Cianjur, Indonesia in 2020. Besides that, another factor that also affects it is age. The results of calculations using the existing equations show that the factors that most influence a person's $\mathrm{Pb}$ intake are the concentration of $\mathrm{Pb}$ in the water consumed, the rate of drinking water 
intake, length of stay, body weight, and frequency of residence. However, what is most likely to be done to control these factors is the rate of water consumption and the concentration of $\mathrm{Pb}$ in the water consumed by the community.

\section{AQ5 References}

1. Haefliger $P$, Nolf $M$, Lociciro $S$, Ndiaye $C$, Coly $M$, Diouf $A$ et al. Mass lead intoxication from infromal used lead-acid baterry recycling in Dakar, Senegal. Environ Health Perspect. 2009;117(10):1535-40. http://doi.org/10.1289/ehp.0900696 PMid:20019903

2. Suksmerri. Impact of lead $(\mathrm{Pb})$ pollution on health. J Kesehatan Masyarakat (Indonesia) 2008;2(2).

3. Palar H. Heavy Metal Pollution and Toxicology. Jakarta, Indonesia: Rineka Cipta; 2008.

4. Widowati W, Sastiono A, Jusuf R. Metal Toxic Effects, Prevention and Pollution Countermeasures. Yogyakarta, Indonesia: CV Andi Offset; 2008.

5. Palar H. Heavy Metal Pollution and Toxicology. Jakarta, Indonesia: Rineka Cipta; 2004.

6. Sunu. Protecting the Environment by Applying ISO 14001. Jakarta, Indonesia: Grasindo; 2001.

7. Agency for Toxic Substances and Disease Registry. Toxicological Profile for Lead. (Draft for Public Comment). Atlanta, GA: U.S. Department of Health and Human Services, Public Health Service; 2019.

8. Fard MP, Mahvi AH, Asgari A, Moradnia M. Heavy metals monitoring in leachate from Landfill site of Qazvin, Iran. Arch Hyg Sci. 2017;6(1):44-48. http://doi.org/10.29252/ ArchHygSci.6.1.44
9. Gworek B, Dmuchowski W, Koda E, Marecka M, Baczewska AH, Brągoszewska $P$, et al. Impact of the Municipal solid waste Łubna Landfill on environmental pollution by heavy metals. Water. 2016;8(10):470. https://doi.org/10.3390/w8100470

10. Van Harling VN. Groundwater Quality Based on Copper [Cu (II)], Manganese [Mn (II)] and Zinc [Zn (II)] Content In Hamlets Around Ngronggo Landfill, Salatiga, Indonesia; 2018.

11. Ashar T, Santi DN, Naria E. Chromium, lead, and mercury in well water on community around landfill. J Kesehatan Masyarakat Nasional (Indonesia). 2013;7(9):408-14.

12. Ministry of Public Works and People's Housing Republic of Indonesia. Human Settlements Directorate Strategic Plan for 2015-2019. Jakarta, Indonesia: Director General of Human Settlements; 2016

13. Santosa, LW. Aquifer Characteristics and Groundwater Potential in Graben Bantul. Yogyakarta, Indonesia: Gajah Mada University Press; 2014.

14. Nurraini Y. Quality of Groundwater around Cipayung Landfill, Depok City. Indonesia: Faculty of Mathematics and Natural Sciences, Universitas Indonesia; 2011.

15. Regulation of the Minister of Health of the Republic of Indonesia Regarding Clean Water Number 416/Menkes/SK/IX/90; 1990.

16. World Health Organization. Nigeria: Mas Lead Poisoning form Mining Activities, Zamfara State. Geneva: World Health Organization; 2010.

17. California Department of Public Health. California Department of Public Health for Occupational Lead Poisoning Prevention Program. Medical Guidelines for the Lead-Exposed Worker. Sacramento, California: California Department of Public Health; 2009.

18. Usia Bertambah, Risiko Gangguan Saraf Meningkat; 2012. Available from: https://lifestyle.kompas.com/ read/2012/10/05/08511234/usia.bertambah.risiko.gangguan saraf.meningkat [Last accessed on 2020 Dec 29].

Author Queries???

AQ1: Kindly provide running title.

AQ2: Kindly provide affiliation.

AQ3: Kindly provide corresponding author details.

AQ4: Kindly provide history details

AQ5: Kindly cite Reference 17 in the text part and also cite in chronological order. 